\title{
Planktonic food and foraging of Eubalaena australis, on Peninsula Valdés (Argentina) nursery ground
}

\author{
Alimento planctónico y forrajeo de Eubalaena australis, en el área de cría de \\ Península Valdés (Argentina)
}

\section{Mónica S. Hoffmeyer, ${ }^{1,5}$ María S. Lindner, ${ }^{2}$ Alejandro Carribero, ${ }^{2}$ Vanesa K. Fulco, ${ }^{4}$ María C. Menéndez, ${ }^{1}$ Melisa D. Fernández Severini, ${ }^{1}$ Soledad L. Diodato, ${ }^{6}$ Anabela A. Berasategui, ${ }^{1}$ Florencia Biancalana ${ }^{1}$ and Eloísa Berrier ${ }^{3}$}

\author{
${ }^{1}$ Instituto Argentino de Oceanografía, Centro Científico Tecnológico Bahía Blanca, CONICET. \\ Camino La Carrindanga km 7.5, B8000FWB Bahía Blanca, Argentina \\ ${ }^{2}$ Fundación Ecocentro. Julio Verne 3784, U9120OJA Puerto Madryn, Argentina \\ ${ }^{3}$ Universidad Nacional de la Patagonia San Juan Bosco. Boulevard Brown \\ 3700, U9120ACV Puerto Madryn, Argentina \\ ${ }^{4}$ Centro Nacional Patagónico, CONICET. Boulevard Brown 3500, \\ U9120ACV Puerto Madryn, Argentina \\ ${ }^{5}$ Facultad Regional Bahía Blanca, Universidad Tecnológica Nacional. \\ 11 de Abril 461, B8000LMI Bahía Blanca, Argentina \\ ${ }^{6}$ Centro Austral de Investigaciones Científicas y Técnicas, CONICET. \\ Dr. Bernardo Houssay 200, V9410CAB Ushuaia, Argentina \\ monica.hoffmeyer@gmail.com
}

\begin{abstract}
Resumen.- Se reportan observaciones sobre alimentación de la ballena franca austral y zooplancton disponible, realizadas en Bahía Pirámides (Golfo Nuevo). Se compararon datos de plancton, comportamiento trófico de las ballenas y temperaturasalinidad y clorofila- $a$ registrados los días 10 y 19 de octubre de 2005. El 19/10 la biomasa zooplanctónica fue significativamente mayor, observándose un número alto de
\end{abstract}

ballenas filtrando en superficie. Esta conducta se observó desde el 17 al 21/10. El evento de forrajeo descrito, confirma que la ballena franca se alimenta en este zona reproductiva de parches de zooplancton con una adecuada composición y alta densidad, en primavera.

Palabras clave: Ballena franca austral, biomasa zooplanctónica, Calanoides cf. carinaus, Calanus australis, eufáusidos

\section{Introduction}

Peninsula Valdés (PV) in Argentina and the Santa Catarina region of Brazil, both in the western South Atlantic, are the main calving-nursery grounds during winter and spring for the southern right whale Eubalaena australis (Desmoulins, 1822) population from the SW Atlantic (Groch et al. 2005, Payne 1986, Rowntree et al. 2001). The whales migrate to these northern most regions of their range, from the feeding grounds in the South Atlantic (Brazil-Malvinas Current Convergence and others) and Sub Antarctic at the beginning of winter, where they are typically found from summer through fall (Payne 1986, Payne et al. 1990, Rowntree et al. 20081).
In these latter areas, southern right whales forage primarily on large zooplankton such as euphausiids and large-size copepods (Pauly et al. 1998, Leaper et al. 2006).

It is not very common to see right whales feeding on their breeding (calving-nursery) grounds, which has been reported as opportunistic or 'out of season feeding' for the northern right whale as well as for the southern right whale population from the South Atlantic eastern coasts (Mayo \& Marx 1990, Best \& Shell 1996, Kenney et al. 1995). Although Payne (1986) had mentioned a low planktonic food abundance for whales in PV in late winter and spring, Sironi (2004), Payne (1995) and others later

${ }^{1}$ Rowntree VJ, LO Valenzuela, P Franco-Fraguas \& J Seger. 2008. Foraging behaviour of southern right whales (Eubalaena australis) inferred from variation of carbon stable isotope ratios in their baleen. Paper SC/60/BRG23 presented to the IWC Scientific Committee, June 2008, Santiago, Chile (unpublished), 10 pp. [Available from: www. Iwcoffice.org/] 
reported that right whales forage sporadically on this nursery ground, from August through November (pers. comm. ${ }^{2}$ ). For instance, Sironi (2004) mentions 20 to 30 whales (including a 1-yr-old female) feeding for 6 hours along an approximately 5-km stretch parallel to the shore in San José Gulf. Furthermore, while taking tourists out to see the whales, whale-watch operators from Pirámides Bay and whales' observers often see whales swimming with their mouths open at the surface, and also diving deep and then returning to the surface with their snouts covered with mud (Carribero \& Lindner pers. observ. ${ }^{3}$ ).

The aim of this study was to record right whale foraging behaviour and the characteristics of zooplankton in Pirámides Bay within Nuevo Gulf, one of the bays where whales have tended to concentrate in recent times and where they are consequently exposed to increasing pressure from the whale-watching industry (Rowntree $e t$ al. 2001). In particular, we describe the zooplankton composition and abundance in samples collected while right whales were foraging on this zone, and compare with that found nine days prior to the observed feeding event, when the whales were not feeding. We also compare the types of prey and abundance levels to those found in the foraging paths of southern and northern right whales and discuss possible factors influencing right whale foraging behaviour in this area.

\section{Material and methods}

Data and samples used in this analysis were obtained in two dates: 10 and 19 of October 2005. These two samplings constituted part of a systematic monthly sampling programme (July to November 2005), carried out at three stations $(1,2,3)$ located on a line into the outer zone (50 - 80 m depth) of Pirámides Bay (PB) (Fig. 1).

At each station and from surface water $(0.5$ to $1.5 \mathrm{~m}$ depth) temperature was registered using a single Celsius protecting thermometer. Sea water samples were also collected using a Van Dorn bottle from near the bottom and at surface, for salinity, chlorophyll- $a$ content and phytoplankton analyses. Additional phytoplankton samples were obtained using $30 \mu \mathrm{m}$ plankton net towed horizontally at the surface and vertically from $60 \mathrm{~m}$ depth, to increase qualitative data and relate with zooplankton characteristics and standing stocks. Zooplankton samples were usually collected by vertical stratified hauls, from near the bottom to the surface (i.e. 0 to $36 \mathrm{~m}$ and 36 to 76 m) using a $200 \mu \mathrm{m}$ Nansen net with closing system.

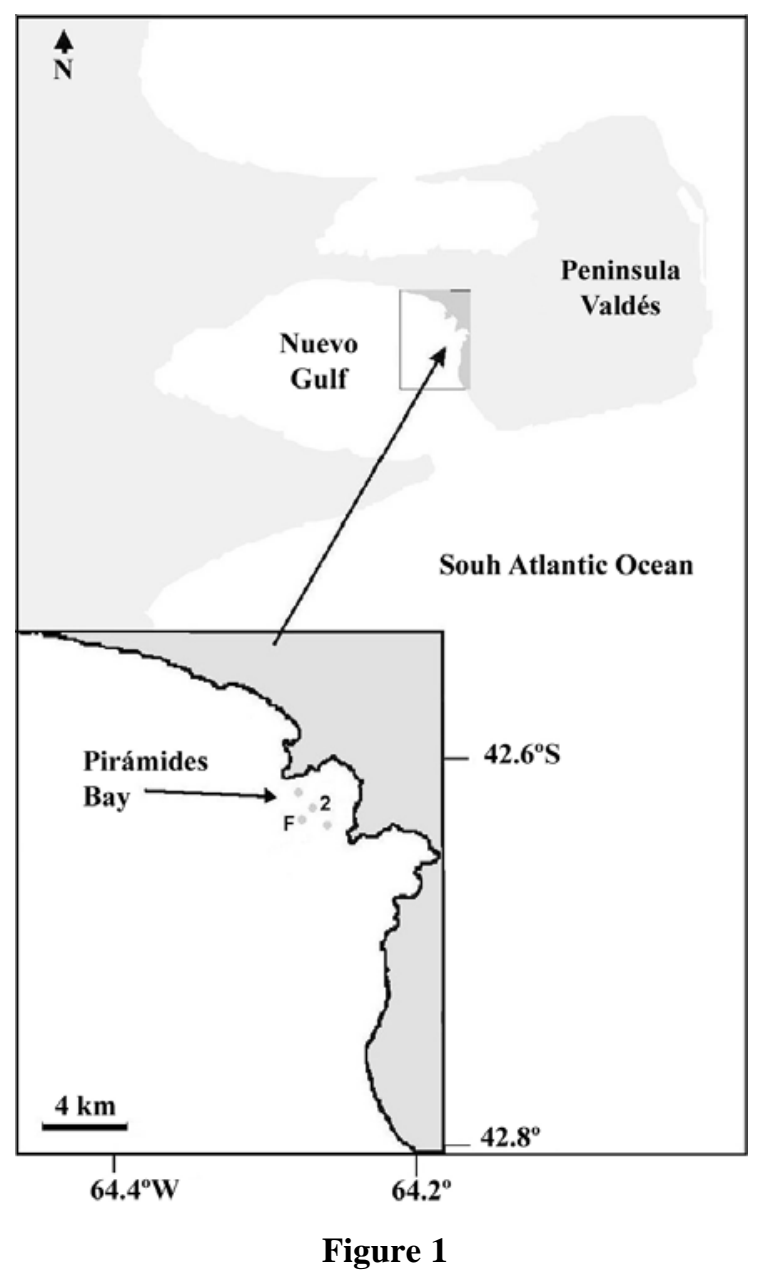

Map of Pirámides Bay and location of sampling stations

Mapa de Bahía Pirámides con la ubicación de
las estaciones de muestreo

On October 10 the three mentioned stations were sampled, but in this report only data from st. $2\left(42^{\circ}\right.$ 36,652'S, 64²18,975'W; $63 \mathrm{~m}$ depth) are shown for comparison. On October 19 two particular points were sampled: -a site close st. 2 (namely from here est. 2'), where whales were skim-feeding and -a site approximately $0.7 \mathrm{~km}$ to the South: namely st. F (42 36,652'S, 64 $19,121^{\prime}$ 'W; 80 m depth), where whales, according to our visual registers, had been foraging at surface and depth, from October 17. On October 19, only at st. 2' a zooplankton sample was collected by a $10 \mathrm{~min}$ horizontal tow into the same whale-foraging stratum (0 to $15 \mathrm{~m}$ depth). Conversely, at st. F, the sampling was

${ }^{2}$ Victoria J. Rowntree, University of Utah, USA, personal comm., June 2008

${ }^{3}$ Alejandro Carribero and Ma. Soledad Lindner, Ecocentro, Pto. Madryn, Argentina, personal observ. 
completed and performed as the usual way described above (at surface and deep strata).

Salinity was measured in the laboratory using a Horiba-10 multiparameter sonde and chlorophyll-a phaeopigments analysed with spectrophotometer following the Lorenzen (1967)'s technique at the Chemistry Laboratory of IADO. Phytoplankton samples were analysed qualitatively and quantitatively using Utermöhl's sedimentation method after Hasle (1978) and inverted microscope at 10-40 X magnification. Zooplankton samples were divided in meso- and macroplankton fractions $(0.2-2 \mathrm{~mm}$ and $2-20 \mathrm{~mm}$, Sieburth et al. 1978), and qualitatively - quantitatively analysed under stereo microscope. Taxa identification was made to the low possible taxonomic level and enumeration was carried out by counting several aliquots. The relative abundance of each taxa in samples was expressed using an arbitrary scale of relative abundance in percent: $\mathrm{P}$, poor (< $30 \%)$, S, scarce (30-40 \%), A, abundant (40-70 \%) and VA, very abundant (70 -100 \%). Biomass by wet weight ( $\mathrm{g} \mathrm{w}^{-3}$ ) was determined according to techniques in Harris et al. (2000). Zooplankton biomass data were statistically analysed applying F to compare variances and the Student's t test for mean comparisons, using the SPSS software package.

In the two sampling dates, the behaviours of whales were recorded. For this, a trained observer using the same whale-watching boat as an observation platform took photographs for the identification of whales and recorded the behaviour of individuals in the area. On October 19, four whale-watch boat departures from the beach were performed with an observer on board, during which behaviour of specimens was observed. Later, at 5 pm there was other departure, with the main objective of taking samples of plankton in the area where whales fed (site close to st. 2 and later at st. F).

\section{Results}

Whales were seen feeding during 5 days between 17 and 21 of October. No other feeding event was detected by us, during the complete sampling programme (July to November).

Data and samples collected on October 10 (st. 2) were used as a close approximation of temperature- salinity chlorophyll-a conditions, zooplankton availability and behaviour of whales whilst not feeding. On that date, some whales were swimming but not feeding at st. 2 located in the central outer zone of PB, at $63 \mathrm{~m}$ depth.

Surface values of temperature and salinity were $11.6^{\circ} \mathrm{C}$ and 34.2 , respectively, whereas surface chlorophyll-a concentration values were high, varying from $2.56 \mu \mathrm{g} \mathrm{l}^{-1}$ at surface to $2.80 \mu \mathrm{g} \mathrm{l}^{-1}$ in depth.

Phytoplankton composition and density showed bloom characteristics, density ranging between 3 and $5 x$ $10^{5}$ cells $\mathrm{l}^{-1}$ from depth (50 $\mathrm{m}$ approximately) to the surface. Diatoms dominated in specific richness and in abundance on dinoflagellates (around 99\% to $<1-5 \%$ of total density). Within diatoms, there were dominant Chaetoceros Ehrenberg and Pseudonitzschia Peragallo (i.e. with some toxic species as $P$. pungens and $P$. fraudulenta, Sastre et al. 2007) genera which are typical of the spring blooms found in this region of Nuevo Gulf (up to $1 \times 10^{6}$ cells l-1 $^{-1}$ Gayoso \& Fulco 2005).

Surface zooplankton samples contained several individuals of the ctenophore Mnemiopsis leidyi A. Agassiz, 1865, a common species in this latitude, in Nuevo Gulf and shelf zones (Esteves et al. 1997, Mianzan 1999), as well as abundant masses of mucus with trapped mesozooplankton. The predominant species in samples from surface and the deep layer were small calanoid and cyclopoid copepods such as Ctenocalanus vanus Giesbrecht, 1888, Paracalanus parvus (Claus, 1863) and Oithona similis Claus, 1866 as well as nauplii and older copepodites (IV and V) of the large copepods Calanoides cf. carinatus (Kroyer), Calanus australis (Brodsky 1959), Centropages brachiatus (Dana, 1849) and nauplii and calyptopes of Euphausia lucens Hansen, 1905. The composition and relative abundance of zooplankton found at st. 2 are shown in Table 1. Holoplankton dominated upon meroplankton in the three samples at both depths. The overall mean standing stocks of zooplankton were low varying from $0.006 \mathrm{~g} \mathrm{~m}^{-3}$ on the bottom to $0.049 \mathrm{~g} \mathrm{~m}^{-3}$ at the surface (mucus-ctenophores remains weight excluded).

On October19, the whale feeding area broadly extended in a southerly direction from the centre of this bay. From 8 am individuals of southern right whale were observed with feeding behaviours, filtering at surface and doing deep dives. Many juvenile and adult whales were observed skim-feeding at the surface in the central part of PB (st. 2) at 5 pm. At least 17 whales were seen feeding as the whale-watch boat approached they continued foraging throughout the entire observation period (hours) without any behavioural changes being detected. The presence of the whale-watch boat did not appear to interrupt the whales' skim-feeding behaviour. Mothers with calves were among the solitary whales, with the calves swimming close to their mothers at all times. One mother with a calf was seen feeding from 8 am until 6 $\mathrm{pm}$. At approximately $3 \mathrm{pm}$, i.e. two hours prior to a multiwhale feeding episode that began at $5 \mathrm{pm}$, a shoal of 
Table 1

Zooplankton composition and relative abundance in October, 2005 at Pirámides Bay, Nuevo Gulf, Argentina. From 10 October, only are shown data of station 2. Su, surface sample; D, deep sample. $P$, poor; S, scarce; A, abundant; VA, very abundant

Composición y abundancia relativa del zooplancton en octubre de 2005 en Bahía Pirámides, Golfo Nuevo, Argentina. Del 10 de octubre se muestran sólo los datos de la estación 2. Su, muestra de superficie; $D$, muestra de profundidad. P, pobre; S, escaso; A, abundante; VA, muy abundante

\begin{tabular}{|c|c|c|c|c|c|}
\hline \multirow{2}{*}{ Taxa } & \multicolumn{2}{|c|}{ Oct 10} & \multicolumn{3}{|c|}{ Oct 19} \\
\hline & st $2 S u$ & st $2 D$ & st $2 S u$ & st F $S u$ & st F $D$ \\
\hline MESOZOOPLANKTON & & & & & \\
\hline Calanus australis (nauplius) & $\mathrm{S}$ & A & $\mathrm{S}$ & A & A \\
\hline Calanus australis (copepodite) & $\mathrm{S}$ & $\mathrm{P}$ & $\mathrm{S}$ & A & A \\
\hline Calanus australis (adult) & $\mathrm{S}$ & A & A & VA & VA \\
\hline Calanoides carinatus (nauplius) & $\mathrm{S}$ & $\mathrm{S}$ & $\mathrm{S}$ & A & A \\
\hline Calanoides carinatus (copep.) & $\mathrm{S}$ & ------- & S & A & A \\
\hline Calanoides carinatus (adult) & $\mathrm{R}$ & -------- & A & A & A \\
\hline Ctenocalanus vanus & $\mathrm{S}$ & $\mathrm{S}$ & ------- & $\mathrm{R}$ & $\mathrm{P}$ \\
\hline Paracalanus parvus & $\mathrm{S}$ & -.---- & $P$ & $\mathrm{R}$ & $P$ \\
\hline Paracalanus sp. & ------. & VA & ------- & ----- & -------- \\
\hline Centropages brachiatus & $\mathrm{S}$ & $\mathrm{S}$ & $P$ & $P$ & $P$ \\
\hline Oithona spp. & A & A & $\mathrm{S}$ & A & A \\
\hline Euterpina acutifrons & ------. & -------- & ------- & ----- & $P$ \\
\hline Harpacticoid copepods & ------ & ------ & ------ & ----- & $P$ \\
\hline Podon sp. & A & A & ------- & $\mathrm{R}$ & $\mathrm{P}$ \\
\hline Evadne normanni & A & VA & VA & $\mathrm{S}$ & $\mathrm{S}$ \\
\hline Euphausia lucens (calyptopes) & ------ & A & VA & VA & VA \\
\hline E. lucens (furcilia) & ------ & -------- & VA & VA & VA \\
\hline Obelia sp. & ------ & ------- & $\mathrm{P}$ & $\mathrm{P}$ & $\mathrm{P}$ \\
\hline Pleurobrachia sp. & ------ & ------- & ------- & $\mathrm{P}$ & $\mathrm{P}$ \\
\hline Decapods (zoea) & $\mathrm{S}$ & $\mathrm{S}$ & $\mathrm{P}$ & $\mathrm{P}$ & $\mathrm{P}$ \\
\hline Echinoderms (larva) & $\mathrm{S}$ & $\mathrm{P}$ & $P$ & $P$ & $P$ \\
\hline Echinoderms (juvenile) & ------. & ------- & $\mathrm{P}$ & $\mathrm{P}$ & $P$ \\
\hline Appendicularians (larva) & A & A & $\mathrm{P}$ & $\mathrm{P}$ & $\mathrm{P}$ \\
\hline Cirripeds (juvenile) & $\mathrm{P}$ & S & $\mathrm{P}$ & $\mathrm{P}$ & $\mathrm{P}$ \\
\hline Gastropods (larva) & ------ & -------- & $\mathrm{P}$ & $P$ & $P$ \\
\hline Bivalves (larva) & $P$ & $\mathrm{P}$ & $\mathrm{P}$ & ----- & ------ \\
\hline Polychaets (larva) & ------ & ------- & $\mathrm{P}$ & $\mathrm{P}$ & $\mathrm{P}$ \\
\hline Hidromedusae & ------ & -------- & ------ & ----- & $P$ \\
\hline Cnidarians (juvenile) & ------ & ------- & ------ & $\mathrm{P}$ & $P$ \\
\hline Fishes (egg) & $\mathrm{S}$ & S & $\mathrm{P}$ & $\mathrm{S}$ & $\mathrm{S}$ \\
\hline $\begin{array}{l}\text { MACROZOOPLANKTON } \\
\text { Calanus australis (adult) }\end{array}$ & $P$ & --- & A & VA & VA \\
\hline Calanoides carinatus (adult) & ------ & ------- & $\mathrm{A}$ & VA & VA \\
\hline E. lucens (calyptopes) & -.---- & ------- & VA & VA & VA \\
\hline Euphausiids (furcilia) & ------- & ------. & VA & VA & VA \\
\hline Obelia $\mathrm{sp}$ & ------- & -------- & $P$ & $\mathrm{P}$ & $\mathrm{P}$ \\
\hline Pleurobrachia sp. & VA & ------- & ------ & $P$ & ------ \\
\hline Decapods (zoea) & ------ & -------- & $P$ & $P$ & $P$ \\
\hline Amphipods & ------ & - & ------ & ----- & $P$ \\
\hline Hidromedusae & ------ & ------- & ------ & ----- & $P$ \\
\hline Fishes (egg) & $P$ & -------- & S & ----- & S \\
\hline Fishes (larva) & ------ & ------. & ------ & ----- & $\mathrm{P}$ \\
\hline
\end{tabular}


anchovy (Engraulis anchoita Hubbs \& Marini) was observed throughout the entire area, accompanied by dolphins and numerous birds.

When plankton samplings were completed (6 pm), some right whales began to dive in the same area (close to st. F, at $80 \mathrm{~m}$ depth) while others continued skimfeeding at the surface. The whales dived and came up with mud on their snouts. Whales continued foraging in the area showing the same feeding behaviour as observed on October 19 for at least the next 3 days (up to October $21)^{4}$. From October 17, a great quantity of whales had been also observed in this latter zone (st. F zone), repeatedly swimming with their mouths open (skimfeeding) and travelling back and forth in parallel lines in an east-west direction. Unfortunately, we were not able to sample plankton and register the water conditions during those prior and posterior dates, but suppose that dense zooplankton patches occurred throughout all that period.

On this date (October 19) at st. F chlorophyll-a concentration in surface water was low $\left(0.45 \mu \mathrm{g} \mathrm{l}^{-1}\right)$ temperature of $10.6^{\circ} \mathrm{C}$ and salinity of 33.9. In phytoplankton, the dominant species were diatoms such as Rhizosolenia setigera Brightwell, 1858, Cylindrotheca closterium (Ehrenb.) Reimann \& Lewin, 1964, Chaetoceros spp. and Pseudonitzschia spp. Density varied from 1,378 cells $\mathrm{l}^{-1}$ at surface to 14,355 cells $\mathrm{l}^{-1}$ in deep sample. These values were $2-3$ orders of magnitude lower than those found in PB on October10.

Zooplankton samples contained 25 taxa finding similar composition and relative abundances of taxa at the two stations (Table 1). Number of meroplankton and adventitious taxa was higher in deep sample from st. F. The large copepod Calanus australis (mainly adults and copepodites V), the cladoceran Evadne nordmanni Lovén, 1836 and also furcilia and calyptopes of Euphausia lucens dominated in samples. Standing stocks of zooplankton did not present significant differences in surface samples of both stations, varying 0.21 (st. F) to $0.40 \mathrm{~g} \mathrm{~m}^{-3}$ (st. 2'). However, these biomass value were one order of magnitude (mesozooplankton: $0.11 \mathrm{~g} \mathrm{~m}^{-3}$, macrozooplancton: $0.29 \mathrm{~g} \mathrm{~m}^{-3}$ and total biomass: $0.40 \mathrm{~g}$ $\mathrm{m}^{-3}$ ) higher than that observed on October 10 at st. 2 (surface: $0.049 \mathrm{~g} \mathrm{~m}^{-3}$ ). Accordingly, mean differences between standing stocks from both dates, were statistically significant $(\mathrm{t}=2.45, P=0.024)$.

${ }^{4}$ MS Lindner, Ecocentro, Pto. Madryn, Argentina, personal observ.

\section{Discussion}

Our findings on the foraging behaviour of southern right whales at PB (Nuevo Gulf) demonstrate that the zooplankton patches in spring may be dense enough to make feeding worthwhile on this nursery ground as that analyzed in this study. Values of biomass found on October 19 at both sampling stations would indicate the effect of whales' consumption on zooplankton density which should be related with records on feeding behaviour.

At these short spatial and temporal scales (kilometres and days) whales' feeding surely act as an effective topdown control of zooplankton patches. On the contrary, the significant differences in zooplankton standing stocks found between two dates could be almost exclusively explained as a consequence of the same plankton succession and production cycle. On October 10, there were the maxima values of the spring phytoplankton bloom and mesozooplankton predation by ctenophores as well. On October 19, it was observed the occurrence of a dense zooplanktonic patch which was forming by the fast post phytoplankton-bloom development of mesoand macrozooplanktonic populations.

It must be pointed that the present data on zooplankton food are biased to the smaller sized zooplankton due to the effect of plankton net used in these samplings (200 micron mesh), which is more efficient for collecting mesozooplankton than macrozooplankton. Then, the biomass values of the latter fraction would be underestimated. So yet, these findings completely confirm the previous visual observations on whales' foraging in this area and provide additional evidence to that of Sironi (2004) (pp. 71-72) on the right whales foraging on euphausiids and copepods in their nursery ground at PV (San José Gulf).

The standing stock values of zooplankton found at surface on October 10, are higher than other biomass estimates known for Nuevo Gulf during the spring phytoplankton bloom at the end of September 1998 (e.g., 0.028 at Nueva Bay to 0.032 at the site Baliza 25 de Mayo, $\left.{ }^{5}\right)$. The values from October 19 patch are in the range of those found in Punta Conscriptos (Nuevo Gulf) $\left(0.12 \mathrm{~g} \mathrm{~m}^{-3}\right)$ in December $1997^{5}$ and higher than those reported in late winter and spring in Nueva Bay, Nuevo Gulf (Esteves et al. 1997) (Table 2). These biomasses (0.09-0.4 $\left.\mathrm{g} \mathrm{m}^{-3}\right)$, are also in the range of the values

${ }^{5}$ MS Hoffmeyer, IADO, Bahía Blanca, Argentina, unpubl. data 


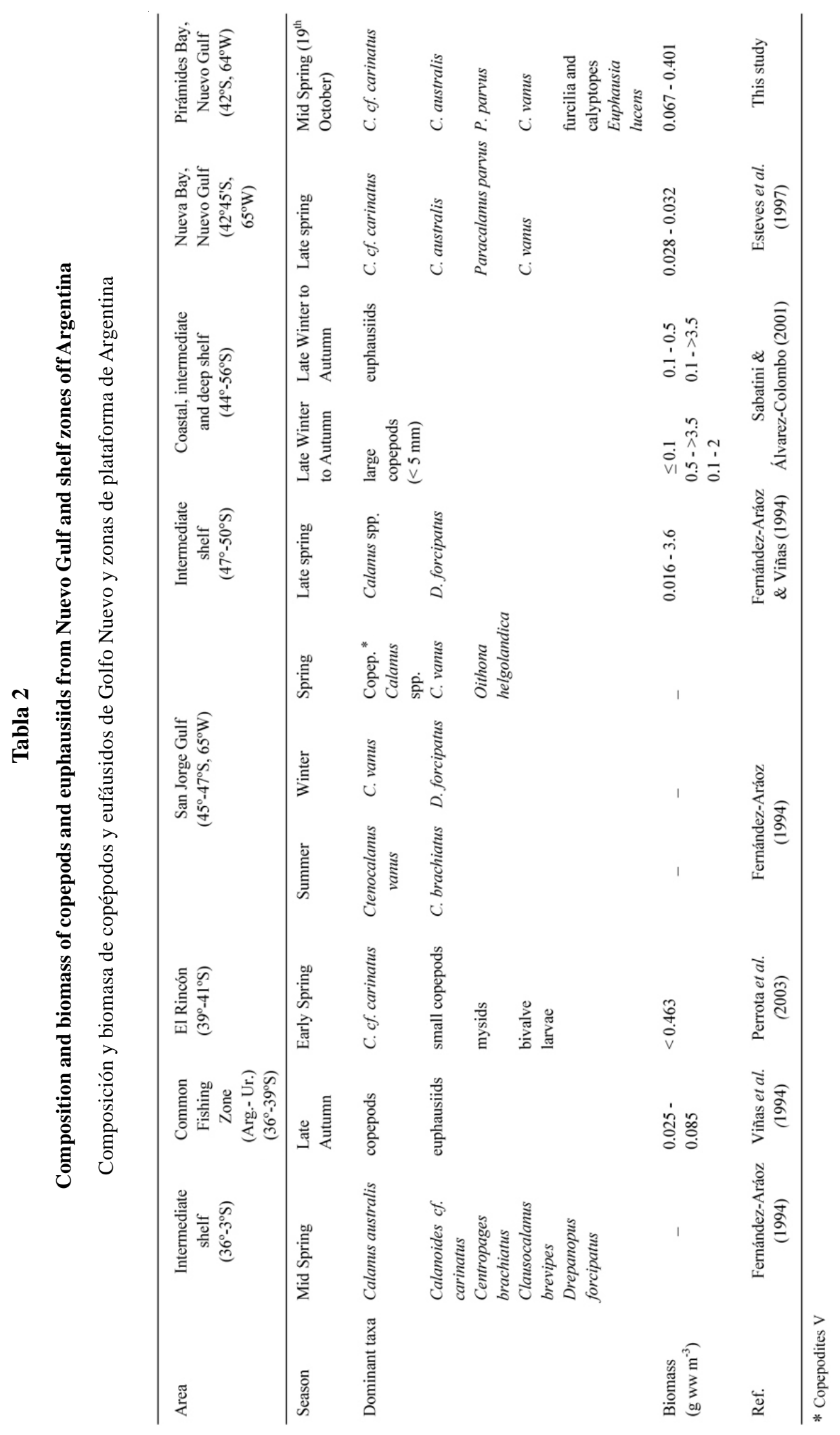


reported for similar and lower latitude regions of the Argentinean Shelf $\left(<0.463 \mathrm{~g} \mathrm{~m}^{-3}\right.$, Perrota et al. 2003) and for some higher latitude regions on the Patagonian Shelf: large copepods 0.5 - >3.5 and euphausiids 0.1-0.5 g $\mathrm{m}^{-3}$ (Sabatini \& Alvarez-Colombo 2001), 0.016-3.6 $\mathrm{g} \mathrm{m}^{-}$ 3 , (Fernández-Aráoz \& Viñas 1994) in late spring, summer and autumn (see Table 2). But these patch biomass values are poor if they are compared to much more dense zooplankton patches (maxima from 1 to $200 \mathrm{~g} \mathrm{~m}^{-3}$ ) reported for the Great South Channel (North West Atlantic), a typical feeding area for the northern right whales (Beardsley et al. 1996).

The composition of patches with a prevalence of large Calanidae copepods and immature euphausiids agrees with that of zooplankton occurring throughout the whales' migratory paths along the Argentinean and Patagonian Shelf during late spring and summer. Also, at higher latitudes, during the late summer and also in autumn, dominance among zooplankton seems to switch to euphausiids (all stages) (Tormosov et al. 1998, Sabatini \& Alvarez-Colombo 2001, Rowntree et al. 2008 ${ }^{1}$ ). The above suggests that whales probably begin to feed at PV before their migration, when they find good palatable food with similar composition and density to those of zooplankton in other probable foraging areas as shown in Table 2.

Northern right whales appear to prefer large calanid copepod patches (Wishner et al. 1988). They are found off Cape Cod and Massachusetts bays in late winter and early spring, where they feed primarily on Calanus finmarchicus (Gunner, 1765) adults and copepodites V as well as small-sized zooplankton forms such as Pseudocalanus spp. Boeck, 1872, Centropages spp. Krøyer, 1849, barnacle larvae and euphausiids (Mayo \& Marx 1990). By mid-spring, northern right whales typically feed in the Great South Channel (Kenney et al. 1995) where again they primarily feed on older copepodite stages (copepodites IV and V) of $C$. finmarchicus (Wishner et al. 1988, 1995, Bearsdley et al. 1996). A good agreement was found between the food types found by us in PV nursery ground: adults and copepodites IV-V of large calanids such as Calanoides cf. carinatus and Calanus australis, with those indicated by these authors.

Faeces of southern right whales collected in the same zone of Peninsula Valdés and on similar dates as observed in our study (end October, 2004) consisted mostly of mandible basis and prosomes of the large copepods $C$. $c f$. carinatus and $C$. australis, and to a lesser extent, carapaces of immature stages of euphausiids (Menéndez et al. 2007). Interestingly, these zooplankton remains belong to the same species as those recorded in the present study. Similarly, in the North Atlantic, exoskeleton remains of $C$. finmarchicus, a large copepod from the northern hemisphere, have been found in faeces collected from northern right whales in Roseway Basin on the southwestern Scotian Shelf (Stone et al. 1988) and this copepod is also the key species in food of the northern right whales.

The diving behaviour observed in these whales was similar to that described by Best (2006) for southern right whales bottom feeding at St. Helena Bay, South Africa. Skim-feeding behaviour was also similar to that described by Sironi (2004) for juveniles and mother/calf southern right whales in San José Gulf and Mayo \& Marx (1990) for North Atlantic right whales. Despite the fact that during this study we did not observe any changes in whale feeding behaviour as a result of the presence of whalewatch boats, other authors have reported potentially adverse short- term responses of whales to boats (Garciarena 1988, Campagna et al. 19956 Rivarola et al. 2001). It is likely that the pressure caused by the increase in this industry, particularly in PB has some effect on whale foraging behaviour.

On the other hand, in a study on right whale harassment by kelp gulls at PV, Rowntree et al. (1998) speculate that the increase in the time mothers swim at relatively high speeds to avoid gull attacks may reduce the blubber reserves they accumulated to feed their calves and to migrate back to their primary feeding grounds. The pressure of the interaction with gulls and its consequences on whale physiology and behaviour could modify whale feeding behaviour on the Valdés nursery ground.

The feeding behaviour observed in southern whales at PV would allow the whales to stay long enough on this nursery ground for their calves to develop more fully before migrating to the feeding grounds as well as to improve the physical condition of adults at the end of spring. Such behaviour appears to correspond to the opportunistic foraging which has been reported for southern and northern right whales during their seasonal migration in late winter and springtime (Mayo \& Marx 1990, Best \& Shell 1996). This pre-migration food supply therefore would supplement the blubber reserves to cover their energetic requirements. However, feeding in Nuevo Gulf could mean a certain risk for whales due to the

\footnotetext{
${ }^{6}$ Campagna C, M Rivarola, D Greene \& A Tagliorete. 1995. Watching southern right whales in Patagonia. Report for the Marine Mammal Action Plan of the United Nations Environment Program, 95 pp. [Available from customerservices@earthprint.co.uk].
} 
sporadic events of harmful algae blooms (HAB) in spring (from Alexandrium tamarense, Gayoso \& Fulco 2006, Esteves et al. 1992, or toxic Pseudonitzschia spp., Sastre et al. 2006) such as that occurred on the start of October 2005 in Pardelas Point, close Pirámides Bay (Sastre et al. 2006). That bloom was coincident with sampling dates of this study and high values of domoic acid (i.e., the Pseudonitzschia spp. neurotoxin) were detected in phytoplankton. In fact, this toxin may travel to high trophic levels and through copepods as vectors to affect whales as it has been reported for this and other phytotoxins (Doucette et al. 2006, Turner et al. 2005).

More in-depth knowledge of the effect of planktonic food availability, variability and suitability on the energetic requirements of whales in PV nursery ground is fundamental to improving the conservation status of the right whale in this zone. The lack of prior studies on the zooplankton composition and abundance at Pirámides Bay, Nuevo Gulf in spring has prevented us from conducting a comparative analysis between years. However, our current findings are a small step towards elucidating the environmental conditions and prey necessary for right whales to begin feeding in spring and a significant advance along the critical pathway towards understanding whale foraging requirements.

In summary, the findings of the present paper add to our understanding of the habitat requirements of southern right whales at the end of their fasting period and will therefore contribute to the conservation of the habitat of these whales on their nursery ground at Peninsula Valdés, Argentina.

\section{Acknowledgments}

Authors are indebted to Mr. J. Orri and to the staff of Whales Argentina Co. and Fundación Ecocentro for their encouragement and assistance in the samplings in Pirámides Bay. Thanks are also due to the Dirección General de Conservación de Áreas Protegidas and Organismo Provincial de Turismo de la provincia de Chubut for allowing us to carry out this study within Peninsula Valdés Reserve. We are very grateful to Victoria Rowntree and Viviana Sastre for her suggestions and critical review of the former English manuscript. We also thank to two anonymous reviewers for their comments and suggestions on the present Ms.

\section{Literature cited}

Beardsley RC, AW Epstein, C Chen, KF Wishner, MC Macaulay \& RD Kenney. 1996. Spatial variability in zooplankton abundance near feeding right whales in the Great South Channel. Deep Sea Research Part II: Topical Studies in Oceanography 43: 1601-1625.
Best PB. 2006. Not all the whales leave in summer! Village Life 19: 14-18.

Best PB \& DM Schell. 1996. Stable isotopes in southern right whale (Eubalaena australis) baleen as indicators of seasonal movements, feeding and growth. Marine Biology 124: 483494.

Doucette GJ, AD Cembella, JL Martin, J Michaud, TVN Cole \& RM Rolland. 2006. Paralytic shellfish poisoning (PSP) toxins in North Atlantic right whales Eubalaena glacialis and their zooplankton prey in the Bay of Fundy, Canada. Marine Ecology Progress Series 306: 303-313.

Esteves JL, N Santinelli, V Sastre, R Diaz \& O Rivas. 1992. A toxic dinoflagellate bloom and PSP production associated with upwelling in Golfo Nuevo, Patagonia Argentina. Hydrobiologia 242: 115-122.

Esteves JL, M Solís, M Gil, N Santinelli, V Sastre, C González-Raies, MS Hoffmeyer \& M Commendatore. 1997. Evaluación de la contaminación urbana de la Bahía Nueva (Provincia del Chubut). Informes Técnicos del Plan de Manejo Integrado de la Zona Costera Patagónica Fundación Patagonia Natural (Puerto Madryn, Argentina) 31: 1-32.

Fernández-Araoz NC. 1994. Estudios sobre la biomasa de Copepoda (Crustacea) con especial énfasis en Calanoida del Atlántico Sudoccidental. Ph D Thesis, Facultad de Ciencias Exactas y Naturales, Universidad Nacional de Mar del Plata, Mar del Plata, 91 pp.

Fernández-Aráoz NC \& MD Viñas. 1994. Biomasa y composición del zooplancton de interés trófico pesquero en áreas del Atlántico Sudoccidental. Campaña H-09/92. Informe Técnico INIDEP 2: 23-33.

Garciarena D. 1988. The effects of whale watching on right whales in Argentina. Whalewatcher 22: 3-5.

Gayoso AM \& VK Fulco. 2005. Occurrence patterns of Alexandrium tamarense (Lebour) Balech populations in the Golfo Nuevo (Patagonia, Argentina), with observations on ventral pore occurrence in natural and cultured cells. Harmful Algae 5: 233-241.

Groch K, JT Palazzo Jr, PAC Flores, FR Adler \& ME Fabian. 2005. Recent rapid increases in the right whale (Eubalaena australis) population off southern Brasil. Latin American Journal of Aquatic Mammals 4: 41-47.

Harris RP, PH Wiebe, J Lenz, HR Skjoldal \& M Huntley. 2000. Zooplankton methodology manual, 684 pp. Academic Press, New York.

Hasle GR. 1978. 7.3 Using the inverted microscope. In: Sournia A (ed). Phytoplankton manual, pp. 191-196. UNESCO, París.

Kenney RD, HE Winn \& MC Macaulay. 1995. Cetaceans in the Great South Channel, 1979-1989: right whale (Eubalaena glacialis). Continental Shelf Research 15: 385414. 
Leaper R, J Cooke, P Trathan, K Reid, VJ Rowntree \& RS Payne. 2006. Global climate drives southern right whale (Eubalaena australis) population dynamics. Biology Letters 2: 289-292.

Lorenzen CJ. 1967. Determination of chlorophyll and phaeopigments: spectrophotometric equations. Limnology and Oceanography 12: 343-346.

Mayo CA \& MK Marx. 1990. Surface foraging behaviour of North Atlantic right whale and associated plankton characteristics. Canadian Journal of Zoology 68: 22142220.

Menéndez MC, AA Berasategui, MS Lindner, SL Diodato, MD Fernández Severini \& MS Hoffmeyer. 2007. Trophic spectrum of southern right whale Eubalaena australis by means of faecal analysis. Biocell 3: 347. [Abstract 87]

Mianzan HW. 1999. Ctenophora. In: Boltovskoy D (ed). South Atlantic zooplankton, 1: 561-573. Backhuys Publishing, Leyden.

Pauly D, AW Trites, E Capulli \& V Christensen. 1998. Diet composition and trophic levels of marine mammals. ICES Journal of Marine Science 55: 467-481.

Payne RS. 1986. Long term behavioural studies of the southern right whale (Eubalaena australis). Report International Whaling Commission, Special Issue 10: 161-67.

Payne RS. 1995. Among whales, 431 pp. Scribner, New York.

Payne RS, VJ Rowntree, JS Perkins, JG Cooke \& K Lankester. 1990. Populations size, trends and reproductive parameters of right whales (Eubalaena australis) off Península Valdés. Report International Whaling Commission, Special Issue 12: 271-78.

Perrotta RG, MD Viñas, AO Madirolas, R Reta, R Akselman, FJ Castro-Machado, AD Garciarena, GJ Macchi, P Moriondo-Danovaro, V Llanos \& JR Urteaga. 2003. La caballa (Scomber japonicus) y las condiciones

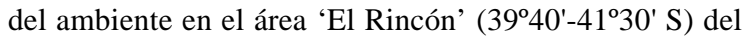
Mar Argentino. Septiembre 2000. Informe Técnico INIDEP 54: 1-25.

Rivarola M, C Campagna \& A Tagliorette. 2001. Demanddriven commercial whalewatching in Península Valdés (Patagonia): conservation implications for right whales. Journal of Cetacean Research \& Management 2 (Special Issue): $145-151$.

Rowntree VJ, P Mcguinness, K Marshall, RS Payne, M Sironi \& J Seger. 1998. Increased harassment of right whales (Eubalaena australis) by kelp gulls (Larus dominicanus) at Península Valdés, Argentina. Marine Mammal Science 14: 99-115.

Rowntree VJ, RS Payne \& DM Schell. 2001. Changing patterns of habitat use by southern right whales (Eubalaena australis) on their nursery ground at Peninsula Valdes,
Argentina, and in their long-range movements. Journal of Cetacean Research \& Management 2 (Special Issue): 133143.

Sabatini ME \& GL Álvarez-Colombo. 2001. Seasonal pattern of zooplankton biomass in the Argentinian shelf off Southern Patagonia $\left(45^{\circ}-55^{\circ} \mathrm{S}\right)$. Scientia Marina 65: 2131.

Sastre V, N Santinelli, G Marino, M Solís, L Pujato \& M Ferrario. 2007. First detection of domoic acid produced by Pseudonitzschia species, Chubut coastal waters, Patagonia, Argentina. Harmful Algae News 34: 12-14.

Sieburth JMCN, V Smetacek \& J Lenz. 1978. Pelagic ecosystem structure: Heterotrophic compartments of the plankton and their relationship to plankton size fractions. Limnology and Oceanography 23: 1256-1263.

Sironi M. 2004. Behaviour and social development of juvenile southern right whales (Eubalaena australis) and interespecific interactions at Península Valdés, Argentina. Ph. D. Dissertation, University of Wisconsin, Madison, 198 pp.

Stone GS, SD Kraus, JH Prescott \& KW Hazard. 1988. Significant aggregations of the endangered right whale, Eubalaena glacialis, on the continental shelf of Nova Scotia. Canadian Field Nature 102: 471-474.

Tormosov D, Y Mikhaliev, P Best, V Zemsky, K Sekiguchi \& RJ Brownell. 1998. Soviet catches of southern right whales Eubalaena australis, 1951-1971 Biological data and conservation implications. Biological Conservation 86:185197.

Turner JT, GJ Doucette, BA Keafer \& DM Anderson. 2005. Trophic accumulation of PSP toxins in zooplankton during Alexandrium fundyense blooms in Casco Bay, Gulf of Maine, April-June 1998. II. Zooplankton abundance and size-fractionated community composition. Deep-Sea Research II 52: 2784-2800.

Viñas MD, BA Santos \& NC Fernández-Aráoz. 1994. Biomasa y composición del zooplancton de interés trófico pesquero en áreas del Atlántico Sudoccidental. Campaña OB-02/91, Zona Común de Pesca Argentino-Uruguaya, mayo-junio 1991. Informe Técnico INIDEP 2: 35-42.

Wishner KF, JR Schoenherr, R Beardsley \& C Chen. 1995. Abundance, distribution and population structure of the copepod Calanus finmarchicus in a springtime right whale feeding area in the southwestern Gulf of Maine. Continental Shelf Research 15: 475-507.

Wishner KF, E Durbin, A Durbin, M Macaulay, H Winn \& R Kenney. 1988. Copepod patches and right whales in the Great South Channel off New England. Bulletin of Marine Science 43: 825-844. 